\title{
Issues and answers concerning passive smoking in the workplace: rebutting tobacco industry arguments
}

\author{
James L Repace, Alfred H Lowrey
}

\begin{abstract}
In response to increased demands for smoke-free workplaces, the multinational tobacco industry has mounted a worldwide public relations campaign to create the appearance of scientific controversy over the health effects and control of environmental tobacco smoke (ETS). We rebut allegations by the tobacco industry and its apologists concerning ETS. We present arguments that show that ETS does cause disease; that ETS is significant relative to other indoor pollutants; that current atmospheric and biological markers for ETS are appropriate; that non-smokers are exposed to sufficient amounts of ETS in workplaces to cause disease; that non-smokers' exposures to ETS have been properly assessed in epidemiological studies; that there is indeed a scientific consensus about the health effects of ETS; and that ventilation or other measures short of eliminating non-smokers' exposures are inadequate controls for ETS.
\end{abstract}

(Tobacco Control 1992; 1: 208-19)

\section{Introduction}

In the United States and other countries there is public demand for restrictions on environmental tobacco smoke (ETS) in the workplace. US surveys show that in $1987,90 \%$ of lifelong non-smokers and $89 \%$ of ex-smokers as well as $80 \%$ of current smokers were in favour of restrictions on smoking in workplaces. ${ }^{1}$ In the United States, however, the occupational health authorities with regulatory authority over workplace air quality have only recently moved tentatively towards regulating smoking at work. ${ }^{2}$

The tobacco industry has argued that restrictions on smoking indoors are unnecessary. It argues, for example, that data on the health effects of ETS are inconclusive; that nonsmokers are exposed to trivial amounts of tobacco smoke compared with smokers; that other indoor pollutants are far more important than ETS; and that solutions other than stringent workplace policies should be pursued - for example, using "common courtesy" to accommodate the needs of both smokers and non-smokers, providing designated smoking areas on the same ventilation system, and improving engineering controls such as ventilation or air cleaning. Because regulatory officials and employers unfamiliar with advances in ETS research may possess inadequate information on such topics, we present specific rebuttals to arguments abstracted from publications, advertising copy, or other statements by the tobacco industry and its allies in the public domain. ${ }^{3,4}$

\section{(1) "Common courtesy controls passive} smoking"

The tobacco industry suggests that nonsmokers bothered by tobacco smoke should "mention annoyances [from ETS] in a pleasant and friendly manner," and that smokers, before lighting up, should tender "the ancient courtesy of 'Do you mind if I smoke?" "5

\section{REBUTTAL}

This in effect requires concerned non-smokers and smokers to canvass all those present in a space and inform them of their preferences or intentions. Thus it is not surprising that when Davis et al analysed the results of the 1987 National Health Interview Survey of 22000 US adults to determine whether common courtesy was being used in passive smoking situations, they found that $47 \%$ of the smokers reported lighting up inside public places without asking if others mind, while only $4 \%$ of non-smokers asked a smoker to refrain. ${ }^{6}$ Davis $e t$ al concluded that these findings show that the common courtesy approach is unlikely to eliminate non-smokers' exposure to ETS. ${ }^{6}$

\section{(2) "Complete elimination of ETS is} unnecessary"

The tobacco industry argues that the premise that workplace exposures to ETS must be eliminated is without adequate supporting data. $^{?}$

\section{REBUTTAL.}

This argument is equivalent to saying it should be presumed that thresholds (defining safe and unsafe levels of exposure) exist for all the diseases of smoking and that all non-smokers have exposures beneath their individual 


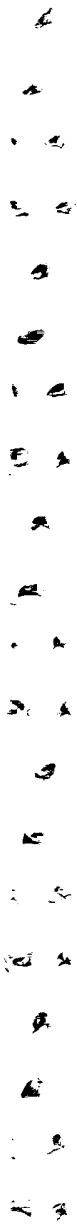

$<3$

$<$

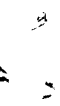

?

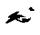

thresholds. The argument runs directly counter to the advice of public health agencies. Given the public health information on the massive harm that smoking inflicts, would such an argument be persuasive if the tobacco industry proposed to add tobacco smoke condensate as an additive to food, beverages, or cosmetics? The US Public Health Service has stated that spacial separation of smokers from non-smokers may reduce, but not eliminate, non-smokers' exposure. In recent public health advisories US public health agencies such as the National Institute for Occupational Safety and Health ${ }^{8}$ and the US Environmental Protection Agency ${ }^{9}$ have proposed smoke-free workplaces or separately ventilated smoking areas, because even low level exposures to carcinogenic agents are presumed to carry an increased risk of cancer. Other options, such as unrestricted smoking, designated smoking and no-smoking areas in a shared space or on the same ventilation system, or increased ventilation and air cleaning, do not eliminate nonsmokers' exposures. ${ }^{10}$

\section{(3) "ETS is far less important than} other indoor pollutants"

The tobacco industry argues that, by focusing on ETS, public health agencies are diverting attention away from more serious workplace problems such as electromagnetic fields, volatile organic compounds, and microbes. They assert that the sick building syndrome, formaldehyde, sulphur oxides, ammonia, oxides of nitrogen, and ozone cause symptoms identical to ETS and that public health authorities have unfairly singled out tobacco smoke, ignoring many "real" threats to public health and safety., ${ }^{71,12}$ (Tobacco industry-sponsored magazine articles aimed at smokers' rights groups have even cited the alleged higherthan-ETS lung cancer risks due to "owning a bird" or "drinking green tea or pasteurised milk.")

\section{REBUTTAL}

ETS risks are among the most serious airborne environmental pollution hazards ever considered by public health agencies. For example, research at the US Environmental Protection Agency has shown that smoking is the largest source of particulate indoor air pollution and is also the major combustion source contributing to total human exposure to mutagens and carcinogens. ${ }^{13}$ In addition, several epidemiological studies have reported the occurrence of health effects when non-smokers breathe ETS at environmental concentrations (so called passive or involuntary smoking). The 1986 US Surgeon General's report stated that a comparison of the chemical composition of the smoke inhaled by active smokers with that inhaled by involuntary smokers suggests that the toxic and carcinogenic effects are qualitatively similar, a result of the fact that both types of smoke derive from tobacco combustion. ${ }^{14}$ Although several epidemiological studies report carcinogenic effects of electromagnetic forces with the same odds ratios as for ETS, a comparison of the odds ratios in epidemiological studies of the risks of ETS and electromagnetic forces is erroneous and highly misleading because the denominators of those ratios pertain to different control groups. Moreover, there is no comparable body of published work implicating electromagnetic forces as a massive cause of cancer at high exposures and little evidence of doseresponse relations. Thus, the weight of evidence against ETS is incomparably stronger than that against electromagnetic fields. To place the relative contribution of ETS as a pollutant into perspective, the impact of ETS on human mortality has been estimated to be two orders of magnitude greater than that of all regulated hazardous outdoor air pollutants combined. ${ }^{15}$

It is also important to note that the symptoms of the sick building syndrome - headaches, dizziness, nausea, and eye, nose, and throat irritation - are also caused by ETS. The irritant chemicals acrolein, acetaldehyde, formaldehyde, sulphur and nitrogen oxides, and ammonia, as well as many other irritating volatile organic compounds, are present in tobacco smoke. The known irritant effects of ETS are indistinguishable from other unknown causes of sick building symptoms.

\section{(4) "There is little evidence, and} nothing which proves scientifically, that cigarette smoke causes disease in nonsmokers." "16

REBUTTAI

This widely advertised statement was challenged as false advertising by health groups in the Australian Federal Court, and after extensive evidentiary hearings a ruling was handed down that scientific evidence does indeed establish cause and effect between passive smoking and lung cancer, as well as asthma and respiratory problems in children. The court enjoined the Australian tobacco industry from continuing to advertise its false claims. ${ }^{16}$

Thru The Smoke Screen, published by the New Zealand Ministry of Health, observes that tobacco industry pronouncements on ETS are deficient in three main areas. ${ }^{17}$

(1) Documents cited by the tobacco industry do not distinguish between refereed journal publications and unrefereed offerings such as letters to the editor; the industry often cites reports of offerings in industry-sponsored symposia or conferences that have not undergone scientific peer review and have less standing in scientific circles.

(2) The tobacco industry chooses published work selectively, ignoring most of the recent work showing the relation between ETS and disease or death.

(3) The tobacco industry misquotes or quotes out of context statements of writers whose work they review. For example, on numerous occasions the tobacco industry has quoted out of context this sentence from an IARC (International Agency for Research on 
Cancer) monograph on tobacco smoke: "The observations on non-smokers that have been made so far are compatible with either an increased risk from passive smoking or an absence of risk." 18 Always omitted, however, is the following sentence, which states in part: "Knowledge of the nature of sidestream and mainstream smoke, of the materials absorbed... and of the quantitative relationships ... commonly observed from exposure to carcinogens, however, leads to the conclusion that passive smoking gives rise to some risk of cancer." 18 Reinken further indicts the tobacco industry for its personal attacks on individual researchers (see, for example, Science 1987 236: 250-1), for its attacks on standard methods of statistical analysis, for focusing on small and inconclusive studies while excluding large well done ones, and for misrepresenting scientific evidence. ${ }^{17}$

Other authors have also observed that the tobacco industry is engaging in an elaborate international campaign to refute the evidence on the harm of passive smoking for three main reasons. Firstly, the passive smoking issue allows a widening of the definition of smoking beyond that of a purely personal behaviour, legitimising it as a social problem. Secondly, successful cases of litigation against employers by workers with histories of long term exposure to ETS have created an industrial climate of concern leading to workplace smoking restrictions and bans. Thirdly, the proliferation of smoking restrictions reduces smoking opportunities and thus reduces total cigarette consumption and hence industry profits. ${ }^{19}$ For example, a survey of smoking rates was made in a Canadian federal workplace by Health and Welfare Canada before and after smoking restrictions. The number of cigarettes smoked at work was reduced by $29 \%$ as a result of restrictions. ${ }^{20}$ Stillman et al reported up to a $20 \%$ reduction following smoking bans in a hospital in the United States. ${ }^{21}$

(5) Existing epidemiological studies of workplace exposures to ETS do not provide adequate support for restrictions against smoking in the workplace $^{11}$

REBUTTAL

Epidemiological studies of passive smoking show that smoking by their spouse is a cause of lung cancer in non-smoking women. Clearly, if exposure to passive smoking at home causes lung cancer, exposure in other places must also carry an increased risk. Several clinical studies have indicated that the workplace is an important source of exposure to ETS. For example, in an international study of urinary cotinine levels in 1369 non-smoking women from 10 countries, Riboli et al found a clear linear increase from the group of women exposed neither at home nor at work to the group of women exposed both at home and at work. ${ }^{22}$ In a similar study of urinary cotinine values in 663 male and female lifelong nonsmokers and ex-smokers in New York State in 1986 Cummings et al found that exposure to
ETS is extremely prevalent, even among those not living with a smoker; the most frequently mentioned sources of exposure were at work and at home. ${ }^{23}$ In another New York State study of 380 lifelong non-smokers a total of $87 \%$ of subjects reported exposure to ETS at work. ${ }^{24}$ Moreover, time budget studies show that the most-frequented microenvironments are the home and the workplace. ${ }^{25}$

Smaller epidemiological studies of passive smoking in the workplace generally have not found a lung cancer effect; however, the world's largest case-control study of passive smoking and lung cancer to date (over 400 cases and 800 controls) has found that whereas smoking by a spouse was associated with a $21 \%$ increased risk of lung cancer (95\% confidence interval 0.96 to 1.54 ), passive smoking in the workplace was associated with a $34 \%$ increased risk of lung cancer $(1.03$ to 1.73 ), and when adenocarcinoma alone was considered, the lung cancer risks associated with both types of exposure increased to about $40 \%$ and were statistically significant. ${ }^{26}$

White and Froeb, in studying the effect of long term workplace passive smoking in 2100 middle aged workers, found that workers who were exposed at work suffered significant declines in pulmonary function (indicative of small airways dysfunction) relative to those who were not exposed at home or at work. ${ }^{27} \mathrm{~A}$ more recent study by Masi et al found that the vital capacity and total lung capacity of men, and the lung diffusing capacity in women, were significantly adversely affected by passive smoking in the workplace. ${ }^{28}$

\section{(6) Non-smoking workers are not} irritated by ETS in the workplace; ETS exposures are below the threshold of discomfort ${ }^{29}$

REBUTTAL

A question on discomfort from cigarette smoke in the workplace was included in the Occupational Health Supplement to the 1988 National Health Interview Survey. This was a cross sectional household interview survey of approximately 44000 adults (aged 18 or more) representative of the US civilian, non-institutionalised population. Among employed nonsmokers who reported that their workplace was not in their home, $36.5 \%$ (or 28.5 million Americans) worked at places that permitted smoking in designated (if any) and other areas. Of these, $43.5 \%$ (12.4 million) reported some or moderate discomfort and $15.7 \% \quad(4.5$ million) reported great discomfort from ETS at the workplace. ${ }^{30}$

Worker discomfort from workplace passive smoking has also been documented by Barad. ${ }^{31}$ Labour-management strife over workplace smoking at the Social Security Administration (SSA) in Baltimore, Maryland, United States, led to a study of 10000 non-smoking workers. Barad found that passive smoking impaired the work efficiency of more than half of the workers. ${ }^{31}$ Thirty-six per cent of the workers reported that they were forced to move away from their workstations to avoid breathing 
smoke, $21 \%$ reported difficulty in concentrating on work because of passive smoking, and $14 \%$ found it difficult to produce work as a result of ETS in the workplace. Frustrated by the lack of resolution by management of its complaints about passive smoking, a group of non-smoking workers filed a suit against the management and pursued the case to the US Supreme Court. The court subsequently dismissed the lawsuit for lack of jurisdiction. ${ }^{32}$

(7) The US National Institute for Occupational Safety and Health has shown that ETS is a sick building problem in only $2-3 \%$ of commercial buildings $^{29}$

REBUTTAI

Although the National Institute for Occupational Safety and Health (NIOSH) has in the past reported that only $2 \%$ of its sick building investigations have dealt with tobacco smoke, ${ }^{33}$ this is misleading. Firstly, although the symptoms of ETS exposure and the sick building syndrome are similar, NIOSH investigators are not likely to be called in when workers are reacting to symptoms which they attribute to environmental tobacco smoke exposure ${ }^{31,34}$ When the cause of complaints is known, it generally becomes a labour-management dispute, resulting in arbitration or litigation. ${ }^{32,34}$ In presentations at indoor air quality seminars we have witnessed NIOSH staff identifying ETS as a significant indoor air pollutant. Secondly, NIOSH staff have stated that the institute currently has no standard method of measuring ETS and has relied upon carbon monoxide measurements as a surrogate. In general, carbon monoxide measurements are not a good indicator for ETS. NIOSH has stated that "the actual role of ETS in relation to building occupant complaints in [NIOSH's] indoor air quality studies has not yet been objectively determined by NIOSH researchers" (K Wallingford, 1991, written communication). Even more importantly, NIOSH recently published an advisory declaring ETS to be a "potential occupational carcinogen" (using legal terminology of the US Occupational Safety and Health Administration [OSHA]) and recommending elimination of tobacco use from the workplace. ${ }^{8}$ OSHA has published a Federal Register notice stating that "secondary tobacco smoke is a recognized health hazard which OSHA is considering for separate regulatory action." ${ }^{2}$

(8) Smokers should have freedom of choice to smoke $^{35}$

REBUTTAL

Smokers should not have freedom of choice to liberate toxic and carcinogenic chemicals in the breathing zone of non-smokers. Smokers can choose to refrain from smoking indoors, can choose to smoke outdoors, or can choose to stop. Non-smokers cannot choose to refrain from breathing. Smokers' pollution harms non-smokers; non-smokers' breathing does not harm smokers. Smokers are on the same moral ground as were spitters around the turn of the century, when public health laws restricted tobacco chewers from spitting on the floor of public buildings. ${ }^{32}$

(9) Components of ETS, even if toxic in other settings, have not been proved to be toxic in ETS ${ }^{7}$

REBUTTAL

Levels of ETS-generated respirable suspended particulates (see argument 10 below) in buildings typically exceed the levels of the National Ambient Air Quality Standards. ${ }^{38}$ Compared with smokers, non-smokers experience low dose exposures to sidestream smoke, exhaled mainstream smoke, and ETS. Smokers are exposed to higher doses of these smoke fractions plus very high doses of mainstream smoke. More than 4700 compounds have been identified in tobacco smoke, of which fewer than 500 are in the gas phase. ${ }^{36}$ At least 43 of these compounds are known human or animal carcinogens. ${ }^{18,37}$ As discussed in the rebuttal to argument 2, there are no known thresholds for carcinogenesis (also see rebuttal to argument 21).

Quantitative comparisons have been made of the mainstream and sidestream smoke of four types of popular US cigarettes. ${ }^{38}$ The analyses generally show that toxic and carcinogenic agents studied are higher in sidestream smoke than in mainstream smoke, and that the carcinogenic potential of indoor pollutants resulting even from low yield cigarettes is not diminished. ${ }^{38}$

Furthermore coexposure to a variety of environmental agents may increase the risk from tobacco smoke: Exposure to radon daughters seems to interact synergistically with tobacco smoke in increasing the risk of lung cancer. ${ }^{39}$ The increased lung cancer risk from coexposure to pulmonary disease-producing occupational dusts such as coal and silica dusts, for example, is additive to that produced by tobacco smoke. Exposure to asbestos produces a synergistic reaction with tobacco smoke for both asbestosis and lung cancer. Other industrial toxicants such as petrochemicals, aromatic amines, and pesticides are also suspected to interact with tobacco smoke exposure and increase disease risk. ${ }^{40}$

(10) Assessment of non-smokers' exposure to ETS is inadequate for risk assessment, and based on outdated studies, questionnaires, or models whose utility in predicting ETS exposures is exaggerated. ${ }^{71,12}$ ETS exposure cannot be assessed using currently available atmospheric markers such as respirable suspended particulate matter (RSP) or nicotine. ETS-derived RSP levels are not a major contributor to workplace air pollution. ${ }^{41}$ 
REBUTTAL

ETS is well established as a major contributor to indoor air pollution, including that of workplaces. ${ }^{34}$ Current studies, questionnaires, and models have shown an ability to predict ETS exposures reasonably well. ${ }^{42-44}$ Models show that ETS concentrations are directly proportional to the smoker density (number of smokers per volume of space) and inversely proportional to the rate of air exchange. In general, if the number of smokers in the space is greater than two, on average, a steady stream of smoke is generated. ${ }^{45} \mathrm{~A}$ number of studies have shown that non-smokers' ETS exposures are determined by the product of the ETS concentration, the duration of exposure, and the respiration rate during exposure ${ }^{38}$ Based upon urinary cotinine studies, Riboli et al have shown that, when appropriately questioned, non-smoking women (upon whom most epidemiological studies of passive smoking are based) can provide a reasonably accurate description of ETS exposure, and that both the duration of exposure and number of cigarettes to which subjects reported being exposed were strongly related to urinary cotinine values. ${ }^{22}$

The significant contribution of ETS to RSP levels indoors has been reported by both the US Surgeon General ${ }^{14}$ and the National Research Council (NRC). ${ }^{25}$ The NRC's report concluded that a majority of field studies have used RSP as an indicator of exposure to ETS because of the "substantial emission of RSP in indoor spaces from tobacco combustion." The NRC also stated that " Total RSP, as measured by personal monitors, has been found to be substantially elevated for individuals who report being exposed to ETS as compared with those who report no exposure," and that "Both air monitoring and modeling clearly indicate that RSP concentrations will be elevated over background levels in indoor spaces when even low smoking rates occur. "25 The Surgeon General concluded that "It has been demonstrated that ETS has resulted in elevated respirable suspended particulate levels in enclosed spaces." 14

Insofar as the contribution of ETS to workplace exposures is concerned, a review of recent work has shown that ETS remains a significant workplace contributor to indoor air pollution. We describe three examples.

(1) Nelson et $a l^{46}$ measured aerosol mass concentration continuously over five 24 hour periods in a $700 \mathrm{~m}^{3}\left(25000 \mathrm{ft}^{2}\right.$ floor area) office with one smoker (daytime occupancy, smoking rate not reported) and an air exchange rate of 1 air change per hour ${ }^{45}$; the large impact on office air caused by smoking is apparent by comparing the daytime office aerosol concentrations (of the order of $50 \mu \mathrm{g} / \mathrm{m}^{3}$ ) during smoking occupancy and evening RSP concentrations (of the order of $18 \mu \mathrm{g} / \mathrm{m}^{3}$ ) during its absence. In modelling the concentration for such an office area, Repace predicted a value for a chain-smoker (smoking at a rate of 6 cigarettes per hour in a volume of $700 \mathrm{~m}^{3}$ at an air exchange rate of 1 per hour, with an
$18 \mu \mathrm{g} / \mathrm{m}^{3}$ background added) of $48 \mu \mathrm{g} / \mathrm{m}^{3}$, consistent with observations. ${ }^{45}$

(2) Nagda et al measured concentrations of RSP in the smoking section of a random sample of 69 smoking and 23 non-smoking flights for the US Department of Transportation. ${ }^{47}$ Non-smoking flight attendants must work in the smoking sections on aircraft where smoking is still permitted - for example, for the United States on most international flights. Levels of RSP on the smoking flights averaged $175 \mu \mathrm{g} / \mathrm{m}^{3}$, whereas RSP measurements in the same section of the aircraft on non-smoking flights averaged 35 to $40 \mu \mathrm{g} / \mathrm{m}^{3}$.

(3) Hammond et al measured personal exposures to RSP in several hundred railroad workers. ${ }^{48}$ Mean calculated ETS-derived exposures to RSP for railroad office workers averaged over $90 \mu \mathrm{g} / \mathrm{m}^{3}$; by comparison, all other sources of RSP for these workers exposed to diesel exhaust averaged only $39 \mu \mathrm{g} / \mathrm{m}^{3}$. Vaughn and Hammond measured weekly average nicotine concentrations in offices in a modern office building using both active and passive samplers. ${ }^{49}$ Before the smoking control policy, nicotine vapour concentrations at nonsmokers' desks were about $2 \mu \mathrm{g} / \mathrm{m}^{3}$; they were reduced by $95 \%$ after a smoking ban was implemented, in good agreement with the findings of Stillman et al. ${ }^{21}$

(11) Markers for ETS in body fluids, such as nicotine and its metabolite, cotinine, are not reliable indicators of ETS exposure. Background levels of nicotine in body fluids are due to diet or persistence of nicotine in the indoor environment and there is no good way to measure uptake of ETS in the body ${ }^{12}$

\section{REBUTTAL}

The 1986 Surgeon General's report ${ }^{14}$ stated that absorption of nicotine by non-smokers has been shown in several countries, suggesting that exposure to ETS is common and that the concentration of nicotine and its metabolite, cotinine, increases in body fluids with self reported ETS exposure. The 1987 IARC report on passive smoking concluded that cotinine has been shown to be a valid and sensitive marker of current exposure to ETS during daily life. ${ }^{50}$ As to the appropriateness of nicotine and cotinine in body fluids as markers for ETS exposure, according to the IARC, cotinine in plasma, urine, or saliva is sufficiently sensitive and specific to identify passive smokers. ${ }^{18}$ Recent studies have reported that nicotine in air from ETS is $60 \%$ to $80 \%$ absorbed by non-smoking women. ${ }^{51}$ PerezStable et al state that a daily consumption of several pounds of vegetables (Solanecae family) would be necessary to produce measurable serum cotinine levels, ${ }^{52}$ while Tunstall-Pedoe et al found that serum cotinine showed little or no association with self reported daily tea consumption. ${ }^{53}$

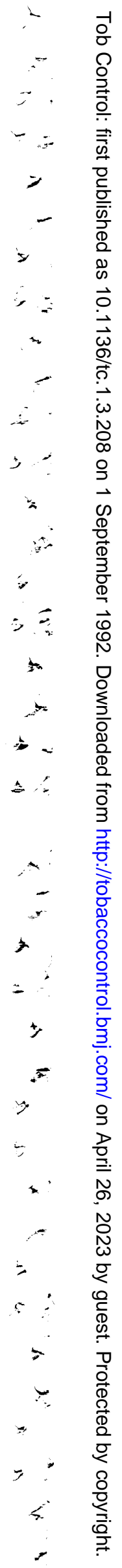


(12) Non-smokers' doses of nicotine and RSP from ETS are too small, when expressed in units of cigarette equivalents, to result in disease ${ }^{54}$

REBUTTAL

The Surgeon General's Report considered the concept of "cigarette equivalents" as a measure of exposure and as an index of risk. ${ }^{14}$ It concluded that the cigarette equivalent calculation, to be meaningful, would have to be done separately for each constituent. When this is done, different constituents have different equivalents. These limitations make extrapolation from atmospheric measures to cigarette equivalents of disease risk "a complex and potentially meaningless process." Moreover, nicotine and RSP are only surrogates for more than 4700 other chemical compounds, among which are 43 known carcinogens. ${ }^{18,37}$

(13) Smoking by a spouse is not a good surrogate for ETS exposure, flawing epidemiological studies of passive smoking and lung cancer or heart disease based on spousal smoking ${ }^{11}$ REBUTTAL

In an international collaborative study of exposure of 1369 non-smoking women to ETS Riboli et al examined the relation between smoking by a spouse and urinary cotinine levels as an indicator of exposure to ETS. ${ }^{22}$ These investigators found that cotinine values were significantly higher for women exposed to ETS from their husband than from other sources; they also found that questionnaires in epidemiological studies based on self reports of a spouse's smoking in fact identified a most exposed population.

(14) Respirable suspended particulate matter (RSP) from ETS is not an important source of indoor air pollution The tobacco industry has argued that sourceapportionment studies show ETS-RSP to be only a small fraction of total suspended particulate matter (TSP); assertions to the contrary are not supported. ${ }^{41}$

REBUTTAL

Leaderer and Hammond measured weekly average vapour phase nicotine and RSP concentrations in 96 residences. Vapour phase nicotine measurements were found to be closely related to number of cigarettes smoked and highly predictive of RSP generated by tobacco combustion. ${ }^{55}$ The mean RSP background in the absence of measurable nicotine was found to be $15 \cdot 2$ (7) $\mu \mathrm{g} / \mathrm{m}^{3}$. The mean RSP value in the presence of nicotine was $44 \cdot 1$ (30) $\mu \mathrm{g} / \mathrm{m}^{3}$. Weekly mean nicotine concentration in the 47 residences with finite nicotine values was $2 \cdot 17 \mu \mathrm{g} / \mathrm{m}^{3}(2 \cdot 43) \mu \mathrm{g} / \mathrm{m}^{3}$.

Miesner et al studied RSP and nicotine work-week average concentrations in 21 workplaces. ${ }^{56}$ In 11 workplaces where nicotine values were above zero the average nicotine concentration was $6.59(7.6) \mu \mathrm{g} / \mathrm{m}^{3}$, and when the two smoking rooms were subtracted, $4.42 \mu \mathrm{g} / \mathrm{m}^{3} \quad(4.8) \mu \mathrm{g} / \mathrm{m}^{3}$. The average RSP concentration in the smoking areas was $110 \mu \mathrm{g} / \mathrm{m}^{3}$ (120) $\mu \mathrm{g} / \mathrm{m}^{3}$, and in the nonsmoking areas was $25 \mu \mathrm{g} / \mathrm{m}^{3}$.

Both chamber and field studies have shown that tobacco combustion has a major impact on the mass of suspended particulate matter in occupied spaces in the size range $<2.5 \mu \mathrm{m}$, defined here as RSP. RSP is a major component of ETS. ${ }^{5-60}$ Even under conditions of low smoking rates, easily measurable increases in RSP have been recorded above background levels. The term RSP, however, encompasses a broad range of particulates of varying chemical composition and size emanating from a number of sources (outdoors, cooking indoors, kerosene heaters, etc).$^{25}$ The apportionment of RSP indoors depends primarily on the presence of these other sources; however, there are few indoor sources generating concentrations which approach in strength those due to ETS. There seems to be little variability between brands of cigarettes or tobaccos for RSP emissions, although cigars will produce greater emissions than cigarettes. ${ }^{58}$ Thus, it may be inferred from a comparison of smoking and non-smoking buildings that the bulk of the RSP found in buildings where there is smoking is due to ETS. For example, by combining the data of First, ${ }^{59}$ Leaderer et $a l,{ }^{60}$ and Repace and Lowrey ${ }^{57,58}$ for a total of 42 smoking buildings and 21 non-smoking buildings, the weighted average RSP level in the smoking buildings is $262 \mu \mathrm{g} / \mathrm{m}^{3}$ compared with $36 \mu \mathrm{g} / \mathrm{m}^{3}$ in the non-smoking buildings, suggesting that about $85 \%$ of the indoor RSP levels in those buildings is due to ETS. Most of the buildings were public access buildings. Repace and Lowrey have suggested that the average population exposure to RSP from ETS is of the order of $1.4 \mathrm{mg} /$ day and that the most exposed non-smokers have $14 \mathrm{mg} /$ day of exposure. ${ }^{61}$ Although Guerin et al have suggested that ETS contributes only $10 \%$ to $50 \%$ of RSP in buildings, ${ }^{62}$ this seems to be an artifact of averaging over periods when there is no smoking. Modelling and measurement in chambers and field studies suggest that the fraction contributed during smoking is actually between $80 \%$ and $90 \% .{ }^{42,45,57,58}$

Recent research has shown that in large office buildings there are many pathways for floor to floor air communication, particularly return air plenums and lift shafts, where the existence of such pathways can cause a building's air exchange characteristics to closely approximate those of a single, large, open space $^{63}$; it does not require unusual numbers or sizes of openings to create these conditions (A Persily, National Institute of Standards and Technology, personal communication, 1987). This implies that ETS may diffuse throughout a large office building, exposing non-smokers even in private offices. Nicotine measurements in office buildings support this observation. ${ }^{50,64}$ 
(15) Studies of Sterling et $a l^{65}$ and Turner et $a l^{66}$ show little or no difference between RSP levels in smoking and non-smoking offices ${ }^{41,67}$

The tobacco industry and its consultants frequently tout these papers, which conclude that "ETS does not appear to contribute significantly to a buildup of contaminants in offices or to be associated with cases of building illness "65 and there is no significant difference between smoking and non-smoking RSP levels in offices. ${ }^{65,66}$

\section{REBUTTAL}

In the case of Sterling $e t a l,{ }^{65}$ a later corrective editorial and two letters to the editor in the same journal found that the paper's conclusions $^{65}$ were not justified by the data presented and were based largely on unpublished data. ${ }^{34,67,68}$ Insofar as the work of Turner et al is concerned, ${ }^{66}$ it has been contradicted by the findings of Turk et $a l^{69}$ and was found to be flawed in its definition of a smoking area. ${ }^{70}$

(16) Risks from exposures to ETS on aircraft are not significant ${ }^{41,71}$

The tobacco industry often cites a paper by Oldaker and Conrad (RJ Reynolds Tobacco Company) which concludes that exposures of non-smokers on aircraft are "orders of magnitude lower than smoking a single cigarette," and that simple separation of smokers from non-smokers on aircraft "significantly reduces ETS exposure of nonsmokers seated in nonsmoking sections of aircraft. " 71

\section{REBUTTAL}

The significance of the risks of exposures to ETS on commercial aircraft has been investigated by Nagda et al for the US Department of Transportation, ${ }^{47}$ as well as by an interdisciplinary team of investigators including researchers from the National Cancer Institute, the Environmental Protection Agency, and academia. ${ }^{72}$ Lifetime risks from ETS exposure estimated by the Department of Transportation study for non-smoking crew members subject to 20 years of occupational exposure were 12 to 16 per $100000,{ }^{47}$ a level which is more than an order of magnitude higher than the maximum de minimis (or "acceptable") risk level used by federal agencies for environmental carcinogens in air, water, or food. ${ }^{16,73}$ Repace estimated proportionally similar risks. ${ }^{74}$ Mattson et al found that ETS exposure on aircraft produced measurable levels of cotinine in the urine of passengers and crew and that objective changes in eye and nose symptoms as well as passengers' perceptions of annoyance and smokiness were significantly related to ETS exposures. ${ }^{72}$

(17) Statements by public health authorities concerning health effects of ETS on children, on people with asthma, or related to heart disease and respiratory disease are not scientifically justified $^{7,11,12}$
REBUTTAL

The technical issues related to heart disease in adults and respiratory symptoms and asthma in adults and children from passive smoking have been addressed by the Surgeon General and the National Research Council, both of which concluded, on the basis of biological plausibility and a wealth of epidemiological studies, that children exposed to ETS suffer increased rates of respiratory infections and symptoms and had slightly diminished lung function. ${ }^{14,25}$

As far as heart disease is concerned, in 1986 , when the Surgeon General's and National Research Council's Reports were issued, there was little information available linking passive smoking to heart disease. ${ }^{14,25}$ However, since then, a substantial body of evidence has accumulated. Glantz and Parmley reviewed the epidemiology, physiology, and biochemistry of passive smoking and heart disease. ${ }^{75}$ They found that 11 epidemiological studies, performed in various places, reflect a $30 \%$ increase in risk of death from ischaemic heart disease or myocardial infarction in nonsmokers living with smokers and that the larger studies show a dose-response effect. Based on this evidence, the American Heart Association's Council on Cardiopulmonary and Critical Care recently concluded that ETS is "a major preventable cause of cardiovascular disease and death," resulting in $>40000$ deaths per year. ${ }^{76}$ An investigator with the National Institute of Occupational Safety and Health (NIOSH) estimated that the individual lifetime excess risk of heart disease death due to ETS is one to three per 100, compared with the much lower excess risk (one death per 100000 ) often used in determining environmental limits for other toxins. ${ }^{77}$

The epidemiological studies on heart disease are complemented by physiological and biochemical data showing that ETS adversely affects platelet function and damages arterial epithelium, increasing the risk of heart disease. ETS also exerts adverse effects on exercise capability of healthy people and those with heart disease by reducing the body's ability to deliver and use oxygen. In animal experiments ETS depresses cellular respiration in mitochondria. Polycyclic aromatic hydrocarbons in ETS also might accelerate, and may initiate, the development of atherosclerotic plaque. Non-smokers seem to be more sensitive to the irritating effects of tobacco smoke than smokers, suggesting non-linear effects in doseresponse. ${ }^{78} \mathrm{~A}$ recent study by Sun et al has experimentally shown the induction of atherosclerotic plaques in rabbits exposed to ETS. ${ }^{79}$ Moreover, there is at least one case where workers compensation is being paid for heart disease induced by passive smoking. A nonsmoking waiter who suffered a heart attack received an $\$ 85000$ settlement in a workers compensation case in California. ${ }^{80}$

(18) Eight scientific symposia on ETS concluded that ETS was a nonproblem $^{11}$ 


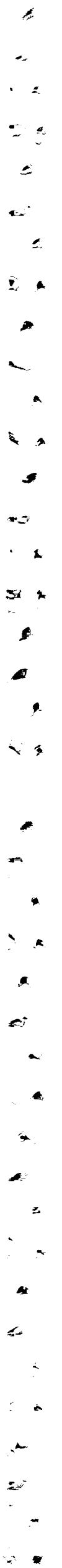

REBUTTAL

These eight symposia, sponsored by the tobacco industry, emphasise the self serving conclusions from papers invited by the industry, presented largely by employees and consultants of the industry, and not subjected to scientific peer review. ${ }^{19}$ (Legitimate papers were also invited to provide a veneer of respectability.) These industry symposia are contradicted by an equal number of risk assessments of ETS exposures and lung cancer published in peer reviewed scientific papers. Repace and Lowrey reviewed nine risk assessments of passive smoking and lung cancer and found that the average among eight of the nine was 5000 (2500) lung cancer deaths per year, corresponding to about $24 \%$ of the annual lung cancer deaths among non-smokers (the 9th estimated that the risk was $<1 \%$ ). ${ }^{15}$ In a 10th risk assessment, Vainio and Partanen have similarly estimated that $20 \%$ to $30 \%$ of the lung cancer deaths in non-smokers are due to passive smoking. ${ }^{81}$ Thus, the overwhelming majority of risk assessments of passive smoking and lung cancer published in scientific papers contradict the tobacco industry symposia and show ETS to be a major public health problem.

(19) Primary lung cancer in nonsmokers is an uncommon disease; most causes are unknown but identified risk factors include radon, diet, and genetics. Most of the studies of passive smoking show a high correlation with adenocarcinoma; there is no correlation between adenocarcinoma and active smoking ${ }^{82,83}$

REBUTTAL

To the contrary, smoking has been related to all four major types of lung cancer: epidermoid, small cell, large cell, and adenocarcinoma; adenocarcinomas have also been induced experimentally by inhalation of dilute tobacco smoke in animals. ${ }^{37,84}$ Although studies in different countries have produced different strengths of association between adenocarcinoma and passive smoking, one histological type does not appear to the exclusion of others. While Fontham et al found a stronger association between passive smoking and adenocarcinoma than for other lung cancers, ${ }^{26}$ Kalandidi et al, in their study of passive smoking and lung cancer, found an increase in all histological types of cancer, but less so for adenocarcinoma. ${ }^{85}$ Thus the histological relationship between passive smoking and adenocarcinoma does not cast doubt on a causal relationship. Although genetics undoubtedly plays some part in the induction of lung cancer, ${ }^{86}$ the major preventable cause of lung cancer in the world today is smoking.

Diet has at best a second order effect on lung cancer.$^{37}$ Dietary influence on lung cancer has been evaluated in the context of passive smoking. In his cohort study of passive smoking in 91540 women, Hirayama found a $12 \%$ decline in risk of lung cancer among nonsmoking women who ate green-yellow vegetables daily but a $125 \%$ increase in lung cancer from passive smoking, a tenfold greater effect. $^{87}$ Kalandidi et al performed a casecontrol study of passive smoking and lung cancer, enrolling 160 women with lung cancer and 160 controls with orthopaedic conditions; high consumption of fruits was inversely related to lung cancer risk, with a relative risk of 0.27 (95\% confidence interval 0.10 to 0.74 ), whereas marriage of a non-smoking woman to a smoker was associated with a relative risk of $2.1(1 \cdot 1$ to $4 \cdot 1){ }^{85}$ The reported associations of lung cancer risk with passive smoking and reduced fruit intake were independent and did not confound each other.

Insofar as radon is concerned, there is no intrinsic reason for radon emissions to be higher in homes of passive smokers than in homes of unexposed non-smokers. Moreover, radon accounted for no more than about a quarter of deaths from lung cancer among non-smokers in $1990 .{ }^{15}$

\section{(20) Misclassification of smokers as} non-smokers can entirely account for the observed risks of passive smoking, and dosimetric estimates of risk conflict with epidemiological estimates of risk $^{88,89}$

REBUTTAL

Lee has suggested that misclassification of smokers as non-smokers can numerically account for the observed risk of passive smoking and lung cancer ${ }^{88}$; however, Wells observed that Lee mixes male and female data, uses suspect sources for estimating misclassification rates, and postulates misclassification rates both in Asian and US women which are not supported by the data. ${ }^{90}$ Moreover, the world's largest study of passive smoking and lung cancer to date, by Fontham et al, ${ }^{26}$ assessed misclassification rates and found that only $0.8 \%$ of cases, compared with $2.6 \%$ of controls with colon cancer and $2.0 \%$ of population controls, were misclassified as non-smokers, indicating that the net effect of misclassification in this study was to bias the odds ratio downwards towards a null effect rather than to increase it.

Dosimetric estimates of risk conflict with epidemiological estimates of risk only if the dose-response curve from active to passive smoking is linear - it is not. ${ }^{78}$

(21) Tobacco smoke in the air is only a symptom of bad ventilation. According to this argument, ETS decreases very rapidly after smoking, does not persist in buildings, and, if uniformly distributed throughout a building, has negligible impact on non-smoking areas with good ventilation.?

REBUTTAL

The essence of this argument is that ventilation is the best control measure for ETS, which is equivalent to saying that dilution is the solution to ETS pollution. In a steady state condition, however, the concentration of tobacco smoke in buildings is directly pro- 
portional to the density of smokers (number of smokers per unit building volume) and inversely proportional to the building air exchange rate. This means that tobacco smoke in the air is not simply a function of "good" or "bad" ventilation, but also a function of the number of smokers in the space and the space volume. If there are three or more smokers in a room, a steady stream of smoke will be generated; the concentration of smoke will increase until equilibrium is attained and will not change unless the smoking rate changes.

This means that tobacco smoke concentrations can be eliminated by eliminating the source, but only reduced by increasing the air exchange rate. Ventilation can reduce the risk of ETS, but if it does not reduce this risk to an acceptable level the reduction is clearly inadequate to protect non-smokers. Thus, ventilation-based controls for ETS cannot be considered as adequate control measures in the absence of health-based national indoor air quality standards for the disease states caused by passive smoking. Currently there are no national standards. We have estimated, however, that to reduce the risk of lung cancer from passive smoking to a de minimis or "acceptable" level by applying federal standards for regulation of environmental carcinogens would require impractical amounts of ventilation or prohibitive costs for air cleaning. ${ }^{61}$ We also estimated that at the ASHRAE (American Society of Heating, Refrigerating, and Air-Conditioning Engineers) Ventilation Standard of 20 cubic feet per minute per occupant (cfm per occupant) $(10 \mathrm{l} / \mathrm{s} /$ occupant $)$ the lung cancer risk to non-smokers in a typical workplace would exceed the maximum de minimis level by more than two orders of magnitude. ${ }^{10,91}$ In existing buildings it is doubtful whether greater increases in ventilation rates than by a factor of two above design levels are even possible without major renovation work, and control of ETS by aircleaning would be uneconomical, costing more than $\$ 30000$ per smoker in 1984 dollars. ${ }^{61}$

ETS in typical buildings does not decrease rapidly after smoking. The mean life for removal of a pollutant from a space is defined as the time it takes for the pollutant concentration to decrease to 1 /e of its initial value (where $\mathrm{e}$ is the base of natural logarithms). It takes three mean lives for $95 \%$ of the smoke to be removed from a building after smoking ceases, where the mean life (in hours) for removal for RSP from ETS is equal to the reciprocal of the air exchange rate (expressed in units of air changes per hour). ${ }^{45}$ For example, at an air exchange rate of 0.25 air changes per hour (ach), typical of a very tight dwelling or commercial building, it would take 12 hours for $95 \%$ of the smoke to be removed, and at the ASHRAE standard of $20 \mathrm{cfm} / \mathrm{occ}$ (about 0.84 ach assuming a $10 \mathrm{ft}(2.83 \mathrm{~m})$ ceiling) it would take 3.6 hours for $95 \%$ of the smoke to be removed from the building. ${ }^{45}$

(22) The American Society of Heating, Refrigerating, and Air-Conditioning
Engineers (ASHRAE) recommendation of 10 litres of outdoor air per second per occupant ( 20 cubic feet per minute per building occupant) is adequate ventilation to deal with "moderate" levels of smoking ${ }^{7,12,41}$

REBUTTAL

North American design air exchange rates are set by ASHRAE Standard 62-1989 ${ }^{92}$ and (insofar as ETS is concerned) are based on design occupancy. These rates are similar to European air exchange rates. ${ }^{42}$ The ASHRAE standard states that "supply rates of ... outdoor air required for acceptable indoor air quality ... have been chosen to control... carbon dioxide and other contaminants with an adequate margin of safety and to account for ... a moderate amount of smoking." Moderate smoking is not defined in the standard. In fact, the treatment of ETS by ASHRAE Standard 621989 was adversely influenced by the tobacco industry. ${ }^{93}$

ASHRAE ventilation rates are not healthbased standards designed to control tobacco smoke to acceptable levels, and compliance with the ventilation rates specified by the ASHRAE standard does not ensure avoidance of health and welfare effects in exposed nonsmokers, as ASHRAE acknowledges. ${ }^{92}$ In fact, data reported by Turk et $a l^{69}$ show that for a group of 38 Pacific Northwest buildings whose measured air exchange rates were on average $70 \%$ higher than prescribed by ASHRAE Standard 62-1989 the RSP levels in smoking buildings averaged $40 \%$ higher than the level of EPA's health-based PM $_{10}$ standard. ${ }^{70}$ Furthermore, at the "moderate" smoking (two cigarettes per smoker-hour; J Janssen, ASHRAE Standard 62 Committee, personal communication) and ventilation rates specified by the ASHRAE standard, risk assessment has indicated that the attendant risk to nonsmoking office workers would be 226 times the maximum acceptable level for airborne carcinogens such as ETS. ${ }^{10,70,91}$

(23) Separation of smokers and nonsmokers on different ventilation systems or total bans on smoking are not the only control options for ETS; separate smoking and non-smoking areas are adequate to minimise exposure ${ }^{7}$

The tobacco industry argues that non-smoking sections in restaurants are adequate control measures. It argues that because ETS is not persistent in buildings, smokers and nonsmokers may share the same space at the same time. It also argues that ventilation with directional flow yields the same results as bans and that a broader range of control options other than separate ventilation and source control is needed.

\section{REBUTTAL}

Non-smoking sections in restaurants do not eliminate non-smoking patrons' exposures to ETS ${ }^{58}$ Moreover, they may actually increase exposures for restaurant service workers. 
Separation in time of non-smokers' and smokers' use of the same space will not be effective unless it is at least three mean-lives (3.6 hours, at ASHRAE standard ventilation (20 cfm/occupant) for an office $)^{45}$ after the end of smoking. Also, ETS absorbed on surfaces will expose non-smokers to unpleasant smells. Directional flow of ventilation from a nonsmoking to a smoking area (so-called plug flow) can yield greater reductions in exposure than simple separation, but it too cannot eliminate non-smokers' exposures because of backstreaming and recirculation of ETS, and it is impractical in existing buildings without major structural and ventilation system modifications. Hammond et al measured nicotine and RSP in two employee smoking lounges at the University of Massachusetts. ${ }^{94}$ RSP levels varied between 220 and $350 \mu \mathrm{g} / \mathrm{m}^{3}$ during smoking, with associated nicotine levels from 40 to $70 \mu \mathrm{g} / \mathrm{m}^{3}$. After charcoal filter air cleaners were installed nicotine levels were virtually unchanged, and RSP levels varied between 100 and $310 \mu \mathrm{g} / \mathrm{m}^{3}$, an inconsequential reduction.

\section{Conclusion}

In a concerted effort to influence employers, regulators, and other policy makers to resist non-smokers' demands for smoke-free workplaces, the multinational tobacco industry has mounted a worldwide public relations campaign with scientific overtones asserting that the health effects data on ETS are inconclusive, that non-smokers are exposed to trivial amounts of tobacco smoke, and that other indoor pollutants are far more important than ETS. The tobacco industry also asserts that workplace smoking policies such as "common courtesy," providing designated smoking areas on the same ventilation system, and increased ventilation or air cleaning are adequate to control ETS in workplaces and are also preferable to smoking bans. This public relations effort is a continuation of the industry's age old strategy of denying the health consequences of tobacco use. We have shown that assertions by the tobacco industry on the risks and control of ETS lack scientific credibility. Employers and policy makers considering the formulation of effective workplace smoking policies should be careful to use credible scientific information from reliable sources whose mission is the protection of public health.

1 Gallup Organisation. Majority backs ban on smoking in public places. Gallup Report No 258, Feb 1987. (Gallup Organisation, Princeton, New Jersey, USA.)

2 Directorate of Compliance Programs, Assistant Secretary for Occupational Safety and Health, Occupational Safety and Health Administration. Indoor air quality. Washington, DC, 22 Oct 1990 . OSHA Notice CPL $2-2$.

3 Comments submitted to the Public Docket: Environmental tobacco smoke: a guide to the development of effective tobacco smoke: a guide to the development of effective workplace smoking policies, 1990. Washington, DC: US Environmental Protection Agency,
review draft. (EPA 400/6-90/004.)

4 Comments submitted to the Public Docket: Health effects of passive smoking: assessment of lung cancer in adults and respiratory disorders in children, 1991 . Washington, DC: US Environmental Protection Agency, May 1990 external review draft. (EPA 600/6-90/006A.)

5 Tobacco Institute. Cooperation is better than legislation. Undated.
6 Davis RM, Boyd GM, Shoenborn CA. "Common courtesy" and the elimination of passive smoking: results of the 1987 National Health Interview Survey. $\mathscr{f} A M A$ $1990 ; 263: 2208-10$. (Errata message published in $\mathcal{F} A M A$ 1990; 263: 3025.)

Tobacco Institute. Comments submitted to the Public Docket. ${ }^{3,4}$

8 National Institute for Occupational Safety and Health. Environmental tobacco smoke in the workplace: lung cancer and other health effects. NIOSH: Cincinnati, June 1991. (Current Intelligence Bulletin No 54.)

9 US Environmental Protection Agency. Indoor Air Facts No 5. Environmental tobacco smoke. Washington, DC: EPA, 1989.

10 Repace JL, Lowrey AN. An indoor air quality standard for ambient tobacco smoke based on carcinogenic risk. $N Y$ State $\mathcal{F}$ Med 1985 85: 381-3.

11 Phillips Morris, Inc. Comments submitted to the Public Docket. ${ }^{3,4}$

12 RJ Reynolds Tobacco Co. Comments submitted to the Public Docket. ${ }^{3,4}$

13 Lewtas J, et al. Indoor air - health. Human exposure and dosimetry of environmental tobacco smoke. Research Triangle Park, North Carolina: Health Effects Research Laboratory, Office of Research and Development, US Environmental Protection Agency, 1990. (US EPA/ 600/1-90/008.)

14 US Department of Health and Human Services, Public Health Service. The health consequences of involuntary smoking. A report of the Surgeon General. Washington, Smoking. A report of the Surgeon General. Washington, 8398.)

15 Repace JL, Lowrey AH. Risk assessment methodologies for passive-smoking-induced lung cancer. Risk Analysis $1990 ; 10: 381-3$

16 Anderson I. Judge backs case against passive smoking. New Scientist 1991 Feb 16.

17 Reinken J. Thru the smoke screen. Wellington: New Zealand Ministry of Health, 1990.

18 International Agency for Research on Cancer. IARC monograph on the evaluation of the carcinogenic risk of chemicals to humans. Tobacco smoking. Lyons: IARC, 1986: 314. (IARC monograph No 38, vol 38.)

19 Chapman S, Borland R, Hill D, Owen N, Woodward S. Why the tobacco industry fears the passive smoking issue. Int f Health Serv 1990; 20 : 417-27.

20 Millar WJ. Evaluation of the impact of smoking restrictions in a government work setting. Can $\mathcal{F}$ Public Health 1988; 79: $379-82$.

21 Stillman FA, Becker DM, Swank RT, et al. Ending smoking at the Johns Hopkins medical institutions: an evaluation of smoking prevalence and indoor air pollution. FAMA 1990; 264; 1565-9.

22 Riboli E, Preston-Martin S, Saracci R, Haley NJ, Trichopoulos $\mathrm{D}$, Becher $\mathrm{H}$, et al. Exposure of nonsmoking women to environmental tobacco smoke, a ten-country collaborative study. Cancer Causes and Control 1990; 1: 243-52.

23 Cummings KM, Mahoney M, Bhargava AK, McElroy PD, Marshall JR. Measurement of current exposure to environmental tobacco smoke. Arch Environ Health 1990; 45: 74-9.

24 Cummings KM, Markello SJ, Mahoney MC, Marshall JR. Measurement of lifetime exposure to passive smoke. Am M Epidemiol 1989;130:122-32.

25 National Research Council. Environmental tobacco smokemeasuring exposures and assessing health effects. Washington, DC: National Academy Press, 1986.

26 Fontham ETH, Correa P, Wu-Williams A, Reynolds P, Greenberg RS, Buffler PA, et al. Lung cancer in nonsmoking women: a multicenter case-control study. Cancer Epidemiology Biomarkers and Prevention 1991; 1: $35-43$.

27 White JR, Froeb HF. Small airways dysfunction in nonsmokers chronically exposed to tobacco smoke. $N$ Engl f Med 1980; 302: 720-3.

28 Masi MA, Hanley JA, Ernst P, Becklake MR. Environmental exposure to tobacco smoke and lung function in young adults. Am Rev Respir Dis 1984; 138: 296-9.

29 Lewis TR. Comments submitted to the Public Docket. ${ }^{4}$

30 US Centers for Disease Control. Discomfort from environmental tobacco smoke among employees at workvironmental tobacco smoke among employees at worksites with minimal smoking restrict
1988. $M M W R$ 1992; 41: 352-4.

31 Barad CB. Smoking on the job: the controversy heats up. Occup Health Saf 1979; 48: 21-31.

32 Repace JL. Risks of passive smoking. In: Gibson M, ed. To breathe freely. Totowa, New Jersey: Rowman and Allanheld, 1985.

33 Melius J, Wallingford K, Keenlyside R, Carpenter J. Indoor air quality: the NIOSH experience. Am Conf Govt Ind Hyg 1984; 10: 3-7.

34 Repace JL, Lowrey AH. Environmental tobacco smoke and indoor air quality in modern office work environments. f Occup Med 1987; 29: 628-9.

35 Rodriguez JF. Comments submitted to the Public Docket. ${ }^{3}$ 36 Dube MF, Green CR. Methods of collection of smoke for analytical purposes. Recent Advances in Tobacco Science analytical purposes.

37 US Department of Health and Human Services. Reducing the health consequences of smoking : 25 years of progress. A report of the Surgeon General, 1989. Atlanta, Georgia: Centers for Disease Control, Office on Smoking and
Health, 1989. (DHHS Publication No (CDC) 89-8411.) 
38 Adams J, O'Mara-Adams $\mathrm{K}$, Hoffmann $\mathrm{D}$. Toxic and carcinogenic agents in undiluted mainstream smoke and sidestream smoke of different types of cigarettes. Carcinogenesis $1987 ; 8: 729-31$.

39 National Research Council. Health risks of radon. Washington, DC: National Academy Press, 1988. (BIER IV report.)

40 US Department of Health and Human Services. The health consequences of smoking : cancer and chronic lung disease in the workplace. A report of the Surgeon General. Washington, DC: Public Health Service, 1985. (DHHS Publication No (PHS) 85-50207.)

41 Healthy Buildings International. Comments submitted to the Public Docket. ${ }^{3}$

42 Repace JL. Indoor concentrations of environmental tobacco smoke: field surveys. In : O'Neill IK, Brunnemann KD, Dodet B, Hoffmann D, eds. Environmental carcinogens: methods of analysis and exposure measurement. Vol 9. Passive smoking. Lyons: International Agency for Research on Cancer, 1987: 141-62.

43 Leaderer BP. Assessing exposures to environmental tobacco smoke. Risk Analysis 1990;10:19-26.

44 Coghlin J, Hammond SK, Gann PH. Development of epidemiologic tools for measuring environmental tobacco

45 Repace JL. Indoor concentrations of environmental tobacco smoke: models dealing with effects of ventilation and room size. In: O'Neill IK, Brunnemann KD, Dodet B, Hoffmann D, eds. Environmental carcinogens: methods of analysis. Vol 9. Passive smoking. Lyons: International Agency for Research on Cancer, 1987: 25-40.

46 Nelson PA, Quant FR, Sem GJ. Experimental measurement of aerosol concentrations in offices. Environment International 1982; 8: 223-7.

47 Nagda NL, Fortmann RC, Koontz MD, Baker SR, Ginevan $\mathrm{ME}$. Airliner cabin environment : contaminant measurements health risks, and mitigation options. US Department ments health risks, and mitigation options. US Departmen
of Transportation Report No DOT P 15895, 1989.

48 Hammond SK, Smith TJ, Woskie SR, Leaderer BP, Bettinger N. Markers of exposure to diesel exhaust and cigarette smoke in railroad workers. Am Ind Hyg Assoc $\mathfrak{f}$ $1988 ; 49: 516-22$.

49 Vaughn WM, Hammond SK. Impact of 'designated smoking area' policy on nicotine vapor and particle concentrations in a modern office building. $\mathcal{F}$ Air Waste Manage Assoc 1990; 40: 1012-7.

50 O'Neill IK, Brunnemann KD, Dodet B, Hoffmann D, eds. Passive smoking. Lyons: International Agency for $\mathrm{Re}$ search on Cancer, 1987. (IARC Scientific Publications No 81.)

51 Iwasi A, Aiba M, Kira S. Respiratory nicotine absorption in nonsmoking females during passive smoking. Int Arch Occup Environ Health 1991; 63: 139-43.

52 Perez-Stable EJ, Marin G, Marin BV, Benowitz NL. Misclassification of smoking status by self reported cigarette consumption. Am Rev Respir Dis 1992; 145: 53-7.

53 Tunstall-Pedoe $H$, Woodward $M$, Brown CA. Tea drinking, passive smoking, and serum cotinine in the Scottish heart health study. 7 Clin Epidemiol 1991; 44: 1411-4.

54 Holcomb L. Comments submitted to the Public Docket. ${ }^{3}$

55 Leaderer BP, Hammond SK. An evaluation of vapor-phase nicotine and respirable suspended particle mass as markers for environmental tobacco smoke. Environmental Science and Technology 1991; 25: 770-7.

56 Miesner EA, Rudnick SN, Preller L, Nelson W. Particulate and nicotine sampling in public facilities and offices. fAPCA 1989; 39: 1577-82.

57 Repace JL, Lowrey AH. Indoor air pollution, tobacco smoke, and public health. Science 1980; 208: 464-72.

58 Repace JL, Lowrey AH. Tobacco smoke, ventilation, and indoor air quality. ASHRAE Transactions 1982; 88: 894-914.

59 First MW. Environmental tobacco smoke measurement: retrospect and prospect. Eur $\mathcal{F}$ Respir Dis $1984 ; 5$ (suppl): 9-16.

60 Leaderer BP, Cain WS, Isseroff G, Berglund LG. Ventilation requirements in buildings. II. Particulate matter and carbon monoxide from cigarette smoking. Atmos Environ 1984; 18: 99-106.

61 Repace JL, Lowrey AH. A quantitative estimate of nonsmokers' lung cancer risk from passive smoking. Environment International 1985; 11: 3-22.

62 Guerin MR, Jenkins RA, Tomkins BA. The chemistry of environmental tobacco smoke: composition and measurement. Boca Raton, Florida: Lewis, 1992.

63 Grot RA, Clark RE. Measured air infiltration and ventilation rates in 8 large office buildings. In: Trechsel $\mathrm{H}$, tilation rates in 8 large office buildings. In: Trechsel $\mathrm{H}$,
Lagus P, eds. ASTM Special Publication 904. PhilaLagus P, eds. ASTM Special
delphia: ASTM, 1986: 151-83.

64 Williams DC, Whitaker JR, Jennings WG. Measurement of nicotine in building air as an indicator of tobacco smoke levels. Environ Health Perspect 1985; 60: 405-10.
65 Sterling T. Environmental tobacco smoke and indoor air quality in modern office work environments, the author replies. F Occup Med 1987; 29: 632-4.

66 Turner S. The measurement of environmental tobacco smoke in 585 office environments. Environment International 1992; 18: 19-28.

67 Sehmer JM. Tobacco smoke and air quality. f Occup Med $1987 ; 29: 637$

68 Kirkbride J. Tobacco smoke and air quality. $f$ Occup $\mathrm{Med}$ 1987; 29: 637

69 Turk BH, Grimsrud DT, Brown JT, Geisling-Sobotka $\mathrm{KL}$, Harrison J, Prill RJ. Commercial building ventilation rates and particle concentrations. $A S H R A E$ Transactions $1989 ;$ 95: 422-33.

70 Repace JL, Lowrey AH. Does ventilation really control environmental tobacco smoke in offices? Environment International 1992; 18: 311-25.

71 Oldaker GB, Conrad FC. Estimation of effect of environmental tobacco smoke on air quality within passvironmental tobacco smoke on air quality within passenger cabins of commercial aircraft.

72 Mattson ME, Boyd G, Byar D, Brown C, Callahan JF, et al. Passive smoking on commercial airline flights. $\mathcal{F} A M A$ $1989 ; 261: 867-72$.

73 Spengler JD, Treitman RD, Tosteson TD, Mage DT, Soczek ML. Personal exposures to respirable particulates and implications for air pollution epidemiology. Environmental Science and Technology 1985; 19: 700-7.

74 Repace JL. Are indoor air quality standards needed? In: Berglund B, Lindvall T, eds. Healthy buildings ' 88 . Vol 4. Conclusions and recommendations for healthier buildings. Stockholm: Swedish Council for Building Research, 1991: 153-9.

75 Glantz SA, Parmley WW. Passive smoking and heart disease: epidemiology, physiology, and biochemistry. disease: epidemiology, phys
Circulation 1991; 83:1-11.

76 Council on Cardiopulmonary and Critical Care, American Heart Association. Circulation 1992;86:1-4.

77 Steenland $\mathrm{K}$. Passive smoking and the risk of heart disease. FAMA 1992; 267 : 94-9.

78 Repace JL. Is the dose-response curve between tobacco smoke exposure and lung cancer linear from active to passive smoking? Environment International 1992;18: $427-9$.

79 Sun Y-P, Zhu B-Q, Sievers RE, Isenberg WM, Glantz SA, Parmley WW. Passive smoking increases experimental atherosclerosis in cholesterol-fed rabbits. Abstract to be presented at the annual meeting of the American Heart Association, 16-19 November 1992, New Orleans, Louisiana, USA.

80 Raeburn P. Waiter wins settlement in claim of heart disease from second-hand smoke. Associated Press $1990 \mathrm{Dec} 14$.

81 Vainio H, Partanen T. Population burden of lung cancer due to environmental tobacco smoke. Mutat Res 1989;
222: 137-40.

82 Adlkofer F. Comments submitted to the Public Docket.

83 Leslie G. Comments submitted to the Public Docket. ${ }^{3}$

84 Morabia A, Wynder EL. Cigarette smoking and lung cancer types. Cancer 1991; 68: 2074-8.

85 Kalandidi A, Katsouyanni K, Voropoulou N, Bastas G, Saracci R, Trichopoulos D. Passive smoking and diet in the etiology of long cancer among nonsmokers. Cancer Causes and Control 1990; 1: 15-21.

86 Bonney GE. Interactions of genes, environment, and lifestyle in lung cancer development. 7 Natl Cancer Inst $1990 ; 82: 1236-7$

87 Hirayama T. Cancer mortality in nonsmoking women with smoking husbands based on a large-scale cohort study in
Japan. Prev Med 1984;13:680-90.

88 Lee PN. Comments submitted to the Public Docket, ${ }^{4}$

89 Rutsch $M$. Comments submitted to the Public Docket. ${ }^{3,4}$

90 Wells AJ. An estimate of adult mortality in the United States from passive smoking: a response. Environment States from passive smoking:
International 1992; 18: 318-25.

91 Repace JL. Effect of ventilation on passive smoking in a model workplace. Proceedings of an engineering foundation conference on management of atmospheres in tightly enclosed spaces, Santa Barbara, 17-21 October 1983. Atlanta: American Society of Heating, Refrigerating, and AirConditioning Engineers, 1984.

92 American Society of Heating, Refrigerating, and AirConditioning Engineers. ASHRAE Standard 62-1989. Atlanta: ASHRAE, 1989.

93 Repace JL. Workshop comments on the dramatic changes in recommended outdoor air rates - what are the rational motives and consequences. In: Berglund $B$, Lindvall $T$, eds Healthy buildings ' 88 . Vol 4. Conclusions and recommendations for healthier buildings. Stockholm: Swedish mendations for healthier buildings. Stockholm:

94 Hammond SK, Leaderer BP, Roche A. Collection and analysis of nicotine as a marker for environmental tobacco smoke. Atmos Environ 1987; 21: 457-62.

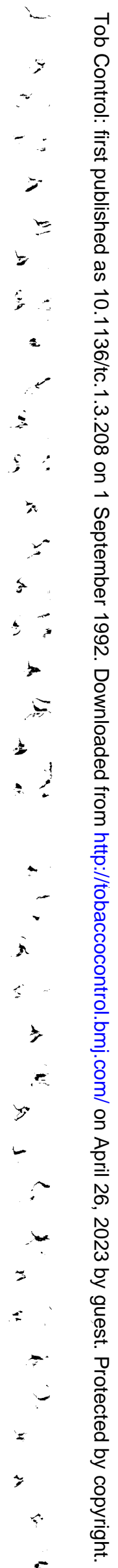




\section{Translations of abstract}

Questions et réponses concernant le tabagisme passif sur le lieu de travail: contrer les arguments de l'industrie du tabac

James L Repace, Alfred H Lowrey

\section{Résumé}

En réponse à une demande accrue pour des lieux de travail sans tabac, l'industrie du tabac multinationale a mis en place une campagne mondiale de relations publiques pour donner l'illusion d'une controverse scientifique sur les effets pour la santé et le contrôle de la fumée de tabac ambiante. Nous controns lesallégations de l'industrie du tabac et de ses défenseurs concernant la fumée de tabac ambiante. Nous présentons des arguments qui montrent que la fumée de tabac ambiante provoque des maladies; que la fumée de tabac ambiante est importante par rapport à d'autres polluants intérieurs; que les marqueurs biologiques et atmosphériques actuels pour la fumée de tabac ambiante sont appropriés; que les non-fumeurs sont exposés à des quantités de tabac dans l'air ambiant suffisantes pour provoquer des maladies; que l'exposition des non-fumeurs à la fumée de tabac dans l'air ambiant a été correctement évaluée dans des études épidémiologiques; qu'il existe un consensus scientifique sur les effets pour la santé de la fumée de tabac ambiante; et que la ventilation ou d'autres mesures qui ne suppriment pas entièrement l'exposition des nonfumeurs sont des moyens inadéquats de contrôle de la fumée de tabac dans l'air ambiant.
Interrogantes y respuestas en torno al tabaquismo pasivo en el lugar de trabajo: refutación de los argumentos de la industria tabacalera

James L Repace, Alfred H Lowrey

\section{Resumen}

En respuesta a la mayor demanda de lugares de trabajo libres de humo de tabaco, la industria multinacional del tabaco ha echado a andar una campaña mundial de relaciones públicas para crear la apariencia de controversia cientifica en torno a los efectos sobre la salud y el control del humo de tabaco ambiental (HTA). Refutamos los argumentos de la industria tabacalera y sus defensores en cuanto al HTA. Presentamos argumentos que muestran que el HTA sí causa enfermedades; que es significativo en relación con otros contaminantes de interiores; que los actuales indicadores atmosféricos y biológicos de HTA son apropiados; que en el lugar de trabajo los no fumadores se ven expuestos a cantidades de HTA suficientes para causar enfermedades; que la exposición de los no fumadores al HTA se ha evaluado adecuadamente en los estudios epidemiológicos; que existe en efecto un consenso científico acerca de los efectos del HTA sobre la salud; y que la ventilación y otras medidas no consiguen eliminar la exposición de los no fumadores ni controlan adecuadamente el HTA.

\section{工作场所被动吸烟的问题和答案：唯穿烟草工业的有关论调 詹姆斯・雷佩思, 阿尔弗雷德・罗利}

要求无烟工作环境的呼声越来越高, 跨国烟草公司对此的反应是, 发动一场全球性的宣 传运动, 企图创造一种“被动吸烟与健康的关系在科学上仍存在着争议”的假象。我们难穿 了烟草工业及他们辩护士的辩解, 并已证实环境烟草烟要确实导致疾病, 环境烟草烟要与其 他室内污染物显著相关。

现行的环境烟草烟雾大气和生物的标准是恰如其分的。不吸烟者在吸入了一定量的环境 烟草烟雾时就会得病。流行病学对暴露于环境烟草烟雾的不吸烟者进行了充分的研究, 环境 烟草烟雾对健康的影响已被许多科学研究所证实, 用增加室内空气流通和其他方法来控制环 境烟票烟票对不吸烟者的影响是不够的，应当让不吸烟者彻底避免暴露于环境烟草烟雾。 